\title{
Differentiation and Activation Phenotypes of Lung T Lymphocytes Differ from Those of Circulating T Lymphocytes
}

\author{
Bruce L. Davidson, Jeffrey Faust, Silvana Pessano, Ronald P. Daniele, and Giovanni Rovera \\ Cardiovascular-Pulmonary Division, Hospital of the University of Pennsylvania, \\ and Wistar Institute of Anatomy and Biology, Philadelphia, Pennsylvania 19104
}

\begin{abstract}
We used dual laser two-color flow cytometry to compare the expression of surface markers associated with activation and with differentiation in lung and peripheral blood $T$ lymphocytes from normal subjects. $T$ cell subsets, defined based on their reactivity with monoclonal antibodies (MAb) OKT3, OKT4, and OKT8, were analyzed for expression of activation antigens as detected by MAbs to the interleukin-2 receptor, the transferrin receptor, and HLA-DR determinants. Whereas circulating $T$ lymphocytes expressed the three activation antigens at low levels, and the total of $\mathrm{T4}^{+}$and $\mathrm{T}^{+}$cells always approximated the number of $\mathrm{T3}^{+}$cells, lung $\mathrm{T}$ lymphocytes of the $\mathrm{T3}^{+}, \mathrm{T4}^{+}$, and $\mathrm{T8}^{+}$populations expressed the activation antigens at variable levels in combinations not seen in circulating lymphocytes, and the sum of $\mathrm{T4}^{+}$and $\mathrm{T8}^{+}$cells always exceeded the $\mathrm{T3}^{+}$total. A proportion of $\mathrm{T4}^{+} \mathrm{T8}^{+}$cells was detected in lung lymphocytes.
\end{abstract}

\section{Introduction}

Considerable interest in the role of $T$ lymphocytes in the etiology and pathogenesis of some human lung diseases has prompted studies of phenotypic and functional characterization of these cells. Cells obtained from bronchoalveolar lavage (BAL) ${ }^{1}$ have shed considerable light on disease processes (1) and have been shown to correspond with those in the lung parenchyma (2). Comparison of $T$ cells obtained from BAL to those circulating in peripheral blood of pulmonary sarcoidosis patients $(3,4)$ has revealed higher ratios of helper/inducersuppressor/cytotoxic $\left(\mathrm{T}^{+} / \mathrm{T}^{+}\right) \mathrm{T}$ cells in the lung. Hypersensitivity pneumonitis has been reported to be associated with lower (5) and comparable (6) T cell ratios in lung vs. blood, while pulmonary fibrosis has been found to have both normal (3) and low (4) ratios.

Address correspondence and reprint requests to Dr. Davidson, Pulmonary Medicine Division, Thomas Jefferson University, Philadelphia, PA 19107. Dr. Pessano's present address is Sorin Biomedica SpA, Saluggia, Italy.

Received for publication 26 October 1983 and in revised form 8 March 1985

1. Abbreviations used in this paper: AMF, alveolar macrophages; AMV, avian myeloblastosis virus; Av-TxR, avidin-Texas Red; BAL, bronchoalveolar lavage; FITC, fluorescein isothiocyanate; IL-2, interleukin2; MAb, monoclonal antibody(ies); PBMC, peripheral blood mononuclear cells; TxR, Texas Red.

J. Clin. Invest.

(C) The American Society for Clinical Investigation, Inc. $0021-9738 / 85 / 07 / 0060 / 06 \$ 1.00$

Volume 76 , July $1985,60-65$
However, these same studies have not always similarly identified BAL $\mathrm{T}$ cell markers in normal subjects. In fact, no systematic study of phenotypic markers of differentiation for BAL $T$ cells in normal subjects exists, largely due to the low total cell yields and low lymphocyte percentages obtained. Total $\mathrm{T}$ cells in BAL in controls have often been quantitated and prepared using rosetting techniques (3), and in one study (5), using an OKT3 monoclonal antibody (MAb), which detects mature $T$ cells. The nonoverlapping nature of the $\mathrm{OKT}^{+}{ }^{+}$and $\mathrm{OKT}^{+}$subsets and the fact that they comprise the total $\mathrm{OKT}^{+}$subset $(4,7)$ have never been demonstrated for other than circulating T cells; concurrent expression of T4 and T8 antigens is the rule in thymic $T$ cell maturation (8). Moreover, recent studies have shown that a large proportion of cells with natural killer activity that are not clearly $\mathrm{T}$ cells form sheep erythrocyte rosettes and bind OKT8 (9), and that circulating monocytes may bind OKT4 (10). Thus, an attempt to characterize the surface phenotype of lung $T$ cells in normal subjects becomes even more important for reference purposes. Differences in $\mathrm{T}^{+} / \mathrm{T}^{+}$ratios in the lung vs. the peripheral blood of patients with immunologic lung diseases could, in part, reflect inherent differences of surface marker expression that exist between circulating and lung $T$ cells in normal subjects.

Similar questions pertain to surface marker expression of BAL T cell activation in controls. We (11) and others (12) have noted in preliminary reports the presence of Ia and Tac antigens on BAL $T$ cells in a few sarcoid patients and normal subjects. Another study assessed BAL cell activation in sarcoidosis and hypersensitivity pneumonitis by flow cytometry analysis of cell cycle stage, but did not include BAL data for normal controls or any surface marker data (13).

To clarify these issues, we sought to characterize surface marker expression on lung $T$ cells in normal nonsmoking controls. Using a two-color technique, we employed dual laser flow cytometry to determine coexpression of multiple differentiation, activation, and cell cycle stage parameters. We found that normal BAL $\mathrm{T}$ cells were mostly noncycling, but expressed activation surface markers on $\mathrm{T}^{+}$cells as well as on $\mathrm{T}^{+}$and $\mathrm{T}^{+}$subsets, and some cells coexpressed both $\mathrm{T}^{+}$and $\mathrm{T}^{+}$ phenotypes.

\section{Methods}

Human subjects. Nonsmoking volunteers between the ages of 21 and 29 with normal chest fluoroscopy and no antecedent history of lung disease gave written informed consent to undergo BAL and venipuncture under a proposal approved by our institutional Human Studies Committee. The technique of BAL has been described in detail $(1,14)$; briefly, after venipuncture with aspiration of $30 \mathrm{ml}$ of blood, volunteers received upper airway topical anesthesia with $2 \%$ lidocaine by aerosol, $0.6 \mathrm{ml}$ atropine was injected subcutaneously, and the fiberoptic bronchoscope was passed to the right middle lobe under direct vision with 
more topical lidocaine anesthesia as required. Up to $400 \mathrm{ml}$ of sterile physiologic saline solution was introduced, and fluid recovery varied from 55 to $70 \%$. BAL cell yields and differential cell counts are shown in Table I.

Preparation of lung and blood cells. Fluid recovered from BAL was poured through 40-gauge steel gauze and cells were centrifuged in the cold. The pellet was washed three times in Hanks' balanced salt solution without $\mathrm{Ca}^{+2}$ or $\mathrm{Mg}^{+2}, \mathrm{pH}$ 7.20. An aliquot was removed for total and differential (by cytocentrifuge) cell counting and viability, determined by customary techniques (15), and the remainder was layered upon Ficoll-Hypaque and centrifuged at room temperature for $40 \mathrm{~min}$. The interface layer was washed three times in MAb buffer $\left(\mathrm{Ca}^{+2}\right.$ - and $\mathrm{Mg}^{+2}$-free phosphate-buffered saline (PBS) with $10^{-2} \mathrm{M}$ EDTA, $0.1 \%$ sodium azide, and $2 \%$ bovine serum albumin, $\mathrm{pH} 7.2$ ) and resuspended to a concentration of at least $2 \times 10^{7}$ cells $/ \mathrm{ml}$. FicollHypaque pellets contained erythrocytes, bronchial epithelial cells, and some lymphocytes, monocytes, occasional granulocytes, and alveolar macrophages (AMF) that stained with trypan blue. Washed interface cells consisted of lymphocytes and AMF.

Peripheral blood was diluted 1:2, layered onto Ficoll-Hypaque, and peripheral blood mononuclear cells (PBMC) were subsequently treated like BAL cells. All samples were handled uniformly and promptly to minimize selective loss of $\mathrm{T}$ cell markers associated with storage and temperature $(16,17)$. Analysis of $T$ cell subset distribution (described below) revealed no selective alterations as a function of filtering through steel gauze or layering onto Ficoll-Hypaque.

Monoclonal antibodies to surface markers. The following MAbs were used: OKT3, OKT4, OKT8 (Ortho Diagnostics, Raritan, NJ) for pan- $T$, helper/inducer, and suppressor/cytotoxic $T$ cell antigens, respectively $(7,8,18)$; anti-human DR $(19,20)$ (Becton-Dickinson \& Co., Mountain View, CA) and SK37-7 (21), which detect nonpolymorphic DR determinants; L5.1, which detects the transferrin receptor (22); anti-Tac (the kind gift of Drs. Thomas Waldmann and Warner Greene, National Cancer Institute, Bethesda, MD), which detects the interleukin-2 (IL-2) receptor $(23,24)$; and S1-37, which detects a transformation antigen (25) in chick myeloblastic leukemic cell lines infected with avian myeloblastosis virus (AMV). S1-37 served as a negative control for nonspecific (Fc receptor) binding. All MAbs were of $\mathrm{IgG}_{2}$ subclass.

Antibody conjugations. Anti-Tac, L5.1, and S1-37 were conjugated with biotin (e.g., Tac-B) by reaction of $1 \mathrm{ml}$ of column-purified antibody $(1 \mathrm{mg} / \mathrm{ml})$ in $0.1 \mathrm{M} \mathrm{NaHCO}(\mathrm{pH} \mathrm{8.4})$ with $120 \mu$ l biotin succinimide ester (Biosearch, San Natale, CA) (dissolved at $1 \mathrm{mg} / \mathrm{ml}$ in dimethyl sulfoxide) at room temperature for $4 \mathrm{~h}$. DR-B was

Table I. BAL Profile of Normal Subjects

\begin{tabular}{|c|c|c|c|c|c|c|c|}
\hline \multirow{2}{*}{$\begin{array}{l}\text { Sub- } \\
\text { ject }\end{array}$} & \multirow[b]{2}{*}{ Sex } & \multirow[b]{2}{*}{ Age } & \multirow{2}{*}{$\begin{array}{l}\text { Cell yield } \\
\times 10^{6}\end{array}$} & \multicolumn{4}{|c|}{ Differential* } \\
\hline & & & & LYM & AMF & PMN & EOS \\
\hline 1 & $\mathbf{M}$ & 26 & 28 & 10 & 89 & 1 & 0 \\
\hline 2 & $\mathbf{F}$ & 28 & 34 & 13 & 84 & 3 & 0 \\
\hline 3 & $\mathbf{F}$ & 21 & 30 & 20 & 79 & 1 & 0 \\
\hline 4 & $\mathbf{F}$ & 23 & 40 & 18 & 81 & 0 & 1 \\
\hline 5 & $\mathbf{M}$ & 26 & 27 & 12 & 88 & 0 & 0 \\
\hline 6 & $\mathbf{M}$ & 24 & 30 & 9 & 91 & 0 & 0 \\
\hline 7 & $\mathbf{M}$ & 25 & 37 & 13 & 85 & 0 & 2 \\
\hline 8 & $\mathbf{M}$ & 24 & 30 & 18 & 81 & 1 & 0 \\
\hline 9 & $\mathbf{F}$ & 29 & 25 & 13 & 86 & 1 & 0 \\
\hline 10 & $\mathbf{M}$ & 26 & 22 & 11 & 88 & 1 & 0 \\
\hline
\end{tabular}

* Percentage of lymphocyte (LYM), AMF, polymorphonuclear leukocytes (PMN), and eosinophils (EOS); at least 200 cells were counted per specimen. purchased and OKT8-B was the kind gift of Dr. Steve Ip (Cambridge Research Laboratories, Cambridge, MA).

Anti-Tac, S1-37, and SK37-7 were conjugated with fluorescein isothiocyanate (FITC; e.g., Tac-FITC) according to the following protocol: column-purified antibody in carbonate buffer (pH 8.7) was added to FITC (15:1 by weight), mixed in the dark at room temperature for $3 \mathrm{~h}$, and recovered from a G-25 Sephadex column. OKT3, OKT4, and OKT8 were purchased as FITC conjugates; a reactive L5.1-FITC conjugate was not obtained.

Avidin-fluorophore conjugates. Second step reagents in the staining system were avidin-FITC (Becton-Dickinson \& Co.) and avidin-Texas Red (Av-TxR), the latter derived by adding $1 \mathrm{ml}$ of avidin (Sigma Chemical Co., St. Louis, MO), dissolved at $5 \mathrm{mg} / \mathrm{ml}$ in carbonate buffer, pH 9.5, to $20 \mu \mathrm{l}$ Texas Red (TxR; Molecular Probes, Junction City, OR) (26) dissolved at $1 \mathrm{mg}$ in $0.1 \mathrm{ml}$ dimethylformamide (Sigma Chemical Co.) with mixing at room temperature for $4 \mathrm{~h}$ in the dark. Free dye was removed on a G-25 Sephadex column equilibrated with PBS, and the first peak (purple) was collected and diluted to $1 \mathrm{mg} / \mathrm{ml}$ in PBS with $0.1 \%$ azide. The TxR-to-avidin molar ratio was 1.8 , as determined by spectrophotometric analysis.

Antibody and fluorophore titration. OKT3-FITC, OKT4-FITC, OKT8-FITC, OKT8-B + Av-TxR, DR-B + Av-TxR, and SK37-7FITC were titrated on $10^{6}$ PBMC for maximum fluorescence. Tac-B + Av-TxR and Tac-FITC were titrated on cells stimulated with phy= tohemagglutinin (Difco Laboratories, Detroit, MI) for $48 \mathrm{~h}$, L5.1-B + Av-TxR on HL60 and K562 cell lines, and S1-37-B + Av-TxR and S1-37-FITC on an AMV-infected chick cell line.

Two-color cell staining. All MAbs and conjugates were appropriately diluted to be present in antibody excess, based on periodic titrations as described above, and centrifuged at $100,000 \mathrm{rpm}$ in a Beckman airfuge for $10 \mathrm{~min}$ before use. Then, $50 \mu \mathrm{l}$ of BAL cells or PBMC in MAb buffer was placed in V-bottom wells in a 96-well microtiter plate with $20 \mu \mathrm{l}$ of the appropriate control or reactive antibody for $30 \mathrm{~min}$ at $4^{\circ} \mathrm{C}$. Wells were washed and centrifuged three times with MAb buffer, and $20 \mu \mathrm{l}$ of avidin-fluorophore or MAb buffer was added to the appropriate wells, followed in $15 \mathrm{~min}$ by $20 \mu \mathrm{l}$ of the appropriate FITC conjugate or MAb buffer. After $30 \mathrm{~min}$, cells were again washed three times, transferred to tubes containing MAb buffer and $2 \%$ paraformaldehyde, fixed overnight, and analyzed by flow cytometry.

Two-color cell cycle analysis was accomplished by a modification of a previously described procedure (27). After surface marker staining with direct FITC or avidin-FITC conjugates and overnight fixation, cells were washed twice in MAb buffer without azide, and RNase A (Sigma Chemical Co.) was added at $500 \mu \mathrm{g} / \mathrm{ml}$ for mixing at room temperature for $30 \mathrm{~min}$. Propidium iodide (Sigma Chemical Co.) at $20 \mu \mathrm{g} / \mathrm{ml}$ was then added, and cells were left for $20 \mathrm{~min}$ at room temperature.

Flow cytometry. Cells were analyzed on the Ortho Cytofluorograf $50 \mathrm{HH}$ (Ortho Instruments, Westwood, MA) using an argon laser (500 $\mathrm{mW}$ at $488 \mathrm{~nm}$ ) for FITC excitation and for forward and right-angle scatter analysis, and a krypton laser $(200 \mathrm{~mW}$ at $568.2 \mathrm{~nm})$ for $T x R$ and propidium iodide excitation. Fluorescence and scatter signals were sensed by photomultiplier tubes. Green fluorescence passed through blue $(>510 \mathrm{~nm})$ and red $(<575 \mathrm{~nm})$ dichroic filters and a $515-530-$ $\mathrm{nm}$ band-pass filter; red fluorescence passed through a blue dichroic and was then reflected by a red dichroic filter before passing through a 590-620-nm bandpass filter. The flow cytometer was calibrated with 1.33- $\mu \mathrm{m}$ diameter fluorescent monodisperse microspheres (Polysciences, Inc., Warrington, PA). Forward and right angle scatter of an unstained sample was used to gate upon the region containing small lymphocytes (Fig. 1). In two sorting experiments, BAL cells in this region were found to contain $>99 \%$ lymphocytes, as judged by alpha-naphthyl butyrate esterase and modified Giemsa stains, the current histochemical standards for evaluating BAL cells (15); the remaining region contained $10 \%$ lymphocytes. Cell analysis of the first region was gated for autofluorescence using S1-37-B + Av-TxR and S1-37-FITC for red and green background, respectively, gated for spillover using positive red and green controls, and four regions of negative, red only, green 


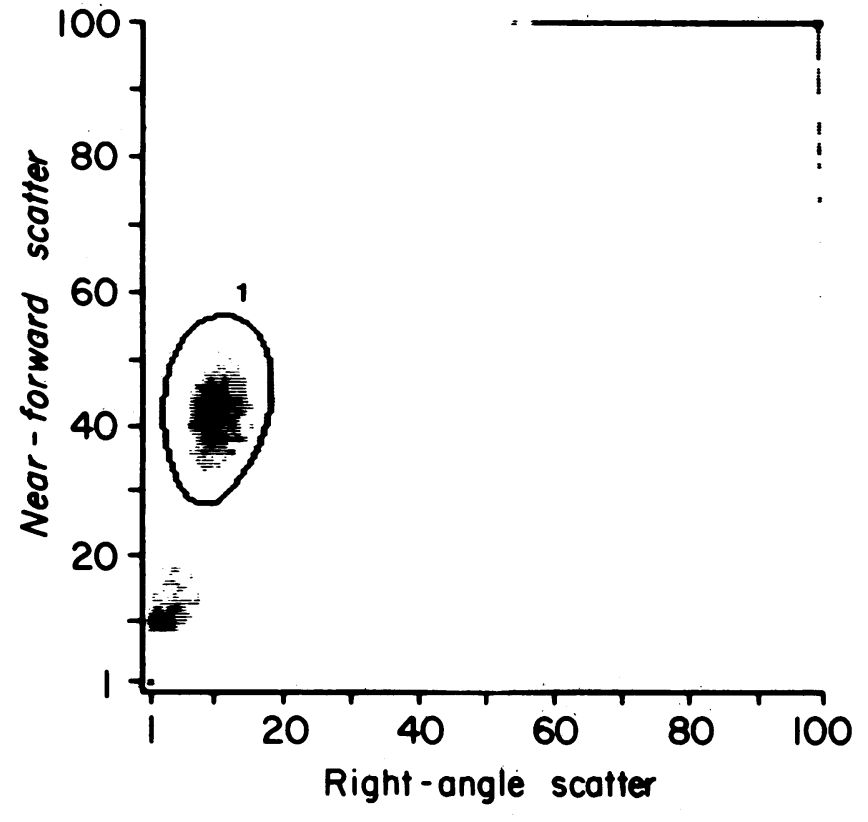

Figure 1. Histogram of BAL cells analyzed. The region marked "1" represents the analyzed lymphocytes; to the lower left are debris and dead cells; on the upper right are monocytes and macrophages. Each dot represents ten cells. (x-axis, right angle scatter; $y$-axis, forward scatter.)

only, and dual-labeled cells were programmed for subsequent sample analysis. At least 5,000 cells in the lymphocyte cluster were counted for each sample, and percent of cells in each gated region was computer calculated. Positive fluorescence thresholds were set at levels where 98\% of control cells were negative, and the percentage of control cells found in the positive regions (always $<3 \%$ ) was subtracted from the test sample to give the net percentage of positive cells. For cell cycle analysis, cells were assigned to $G_{0} / G_{1}$ or $S / G_{2} / M$ phases by their location in a DNA histogram (27); surface marker staining in each phase was computer determined.

\section{Results}

Differentiation antigens. The proportion of $\mathrm{T}^{+}$cells in peripheral blood of subjects studied (mean 68\%; Fig. 2) equaled the sum (within $5 \%$ ) of $\mathrm{T}^{+}$and $\mathrm{T}^{+}$cells; $<2 \%$ of lymphocytes ever expressed both $\mathrm{T} 4$ and $\mathrm{T} 8$ antigens, consistent with prior reports $(7,8)$. In contrast, lung $T$ lymphocytes (Table II) showed a decreased proportion of $\mathrm{T}^{+}$cells (mean $49 \%$ ), and the sum of the $\mathrm{T}^{+}$and $\mathrm{T}^{+}$cells always exceeded the $\mathrm{T}^{+}$ total, although $\mathrm{T} 4 / \mathrm{T} 8$ ratios were within the normal range (mean 1.9). Two-color immunofluorescence analysis of $\mathrm{T}^{+}$

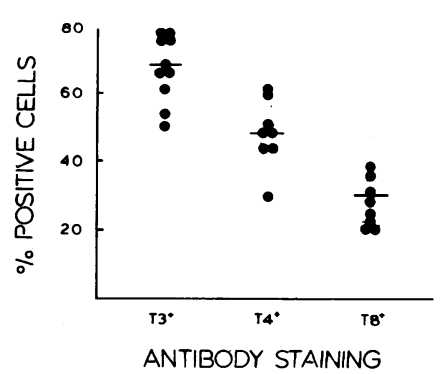

Figure 2. Peripheral blood T cell differentiation antigens. Surface marker $\mathrm{T}$ cell phenotypes of normal controls. Horizontal bars represent means of percentages of cells binding to the respective MAbs, with background fluorescence subtracted.
Table II. Lung T Lymphocyte Differentiation Antigens

\begin{tabular}{|c|c|c|c|c|c|c|}
\hline \multirow{2}{*}{$\begin{array}{l}\text { Sub- } \\
\text { ject }\end{array}$} & \multicolumn{5}{|c|}{$\begin{array}{l}\text { Percentage positive cells binding } \\
\text { to monoclonal antibodies }\end{array}$} & \multirow{2}{*}{$\begin{array}{l}\text { Ratio of T4 to } \\
\text { T8-positive cells }\end{array}$} \\
\hline & $\mathrm{T} 3$ & T4 & $\mathrm{T} 8$ & $(T 4+T 8)^{*}$ & T4T8‡ & \\
\hline 1 & 32 & 43 & 29 & ND§ & ND & 1.5 \\
\hline 2 & 31 & 36 & 15 & ND & ND & 2.4 \\
\hline 3 & 75 & 72 & 33 & ND & ND & 2.2 \\
\hline 4 & 27 & 58 & 16 & ND & ND & 3.6 \\
\hline 5 & 61 & 46 & 51 & 75 & ND & 0.9 \\
\hline 6 & 66 & 79 & 35 & 82 & ND & 2.3 \\
\hline 7 & 52 & 52 & 29 & 81 & ND & 1.8 \\
\hline 8 & 64 & 67 & 44 & 73 & 16 & 1.5 \\
\hline 9 & 51 & 66 & 30 & 67 & 16 & 2.2 \\
\hline 10 & 28 & 28 & 23 & 52 & 7 & 1.2 \\
\hline
\end{tabular}

* Percent-positive staining with the two FITC-conjugated antibodies added to the same sample.

¥ Double-labeled cells by two-color staining.

$\S$ Not determined.

and $\mathrm{T}^{+}$cells revealed a $\mathrm{T}$ cell population bearing both markers in three subjects studied (Fig. 3, Table II).

Activation antigens. Two-color staining to distinguish the

A

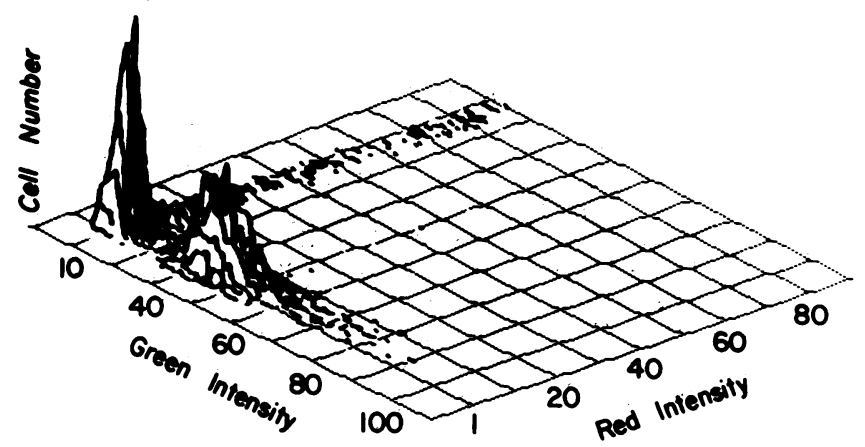

B

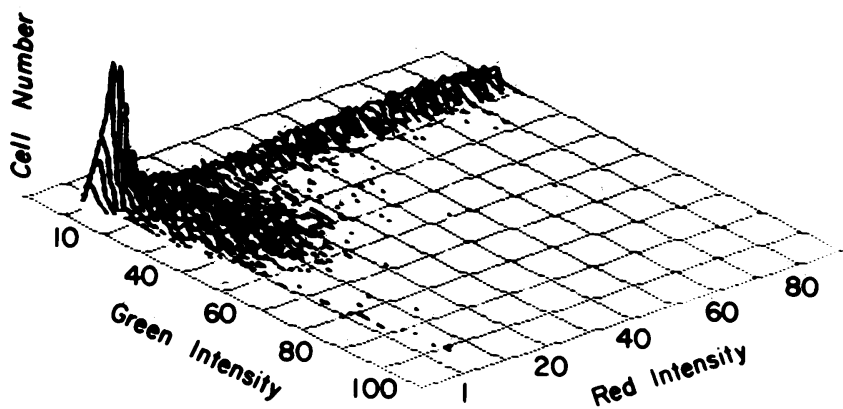

Figure 3. $\mathrm{T}^{+} \mathrm{T}^{+}$cells in lung, but not in peripheral blood. Threedimensional histograms of cells binding to MAb T4 (x-axis; green), MAb T8 (y-axis; red) and double-labeled cells. The height of each peak corresponds to relative cell number. $(A)$ Peripheral blood lymphocytes. $51 \%$ of cells were $\mathrm{T}^{+}, 23 \% \mathrm{~T}^{+}$, and $1 \% \mathrm{~T}^{+} \mathrm{T}^{+}$. $(B) \mathrm{BAL}$ lymphocytes. $58 \%$ of cells were $\mathrm{T}^{+}, 34 \%$ were $\mathrm{T}^{+}$, and $16 \%$ were $\mathrm{T}^{+}{ }^{+} 8^{+}$. 


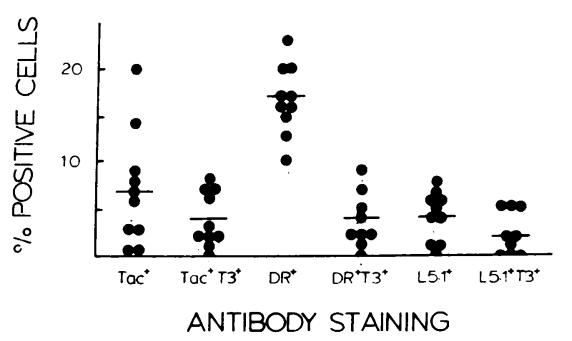

Figure 4. Peripheral blood activation antigens. Single- and doublelabel staining of lymphocytes for activation and T3 antigens. Horizontal bars represent means of values for all subjects.

presence of Tac, DR, and L5.1 antigens on mature circulating $\mathrm{T}\left(\mathrm{T}^{+}\right)$cells revealed only a small proportion of dual-labeled cells (Fig. 4). Very variable percentages of lung lymphocytes displayed activation antigens (Table III). While some subjects showed $<7 \% \mathrm{Tac}^{+}$cells, subjects 3,5 , and 6 showed elevated Tac expression on $\mathrm{T}^{+}, \mathrm{T}^{+}$, and $\mathrm{T}^{+}$cells. The sum of $\mathrm{Tac}^{+} \mathrm{T}^{+}$and $\mathrm{Tac}^{+} \mathrm{T}^{+}$cells always exceeded the $\mathrm{Tac}^{+} \mathrm{T}^{+}$cells (Table III). Subjects $1-3,5,6$, and 10 showed elevated L5.1 binding to $\mathrm{T}^{+}, \mathrm{T}^{+}$, or $\mathrm{T}^{+}$cells. The sum of $\mathrm{L}_{5.1^{+}} \mathrm{T}^{+}$and $\mathrm{L} 5.1^{+} \mathrm{T}^{+}$cells also exceeded the number of $\mathrm{L} 5.1^{+} \mathrm{T} 3^{+}$cells.

While the proportion of $\mathrm{DR}^{+}$cells was as high as $45 \%$ on all lung lymphocytes, it never exceeded $39 \%$ on cells coexpressing either $\mathrm{T} 3, \mathrm{~T} 4$, or $\mathrm{T} 8$ antigens. Decreased $\mathrm{T} 3$ expression and $\mathrm{T}^{+}{ }^{+} \mathrm{T}^{+}$coexpression prevent an accurate determination of the total $\mathrm{T}$ cell population and thus of the proportion of total $\mathrm{DR}^{+} \mathrm{T}$ cells; nonetheless, as with the Tac antigen, the presence of both $\mathrm{DR}^{+} \mathrm{T}^{+}$and $\mathrm{DR}^{+} \mathrm{T}^{+}$small lymphocytes in normal subjects can be demonstrated.

Simultaneous expression of activation antigens was studied on lung lymphocytes of six subjects (Table IV). Dual staining for Tac and DR revealed a proportion of $T$ cells expressing both antigens (subject 5). A maximum of 5\% of lymphocytes coexpressed L5.1 and DR, although neither of these latter antigens are specific for $\mathrm{T}$ lymphocytes and may be identifying activated or proliferating B cells $(22,28,29)$.

Cell cycle analysis. In four subjects studied by two-color cell cycle analysis in which DNA-stained cells accounted for $>80 \%$ of the lymphocyte population, nearly all cells were nonproliferating in $\mathrm{G}_{0} / \mathrm{G}_{1}$ (Table $\mathrm{V}$ ). The majority of $\mathrm{Tac}^{+}$ and $\mathrm{DR}^{+}$cells were found in this population, although a few were found in cells with increased DNA staining identifying the latter as actively dividing cells. Again, not all $\mathrm{DR}^{+}$cells showed $\mathrm{T}$ differentiation antigens, and some may be dividing B cells.

\section{Discussion}

Cell surface marker phenotyping by the binding of immunologically-specific MAbs has proven a powerful tool in dissecting patterns of cell participation in physiologic and pathologic immune processes, and knowledge of the functional specificity and significance of surface antigens continues to expand.

The differentiation antigen T3, found on circulating lymphocytes, not only identifies the mature $T$ cell but in association with clonotypic $\mathrm{Ti}$ antigen appears to be the $\mathrm{T}$ cell receptor complex for antigen. Modulation (loss) of T3 antigen from the cell surface inhibits antigen-specific proliferation and cytotoxic capabilities, and enhances response to IL-2. The T3-Ti antigen complex appears at a late stage in thymic $\mathrm{T}$ cell ontogeny, and confers immunocompetence, which develops further when thymic lymphocytes are exported $(8,30)$.

In data obtained from studies of several patients with pulmonary sarcoidosis or hypersensitivity pneumonitis $(4,5$, 11), T3 expression in the BAL lymphocyte gate has been $\geq 75 \%$, as compared with our finding in 10 normal subjects of a mean value of $49 \%$. The diminished T3 molecule expression on BAL lymphocytes of these normal subjects might be explained by either or both of two mechanisms: (1) modulation as a result of antigenic stimulation in the normal lung; and (2) incomplete in situ pulmonary maturation of partially differentiated $\mathrm{T}$ cells.

Concurrent expression of T4 and T8 antigens is the rule in stage II maturing thymocytes, which later further differentiate in the thymus, segregating into reciprocal $\mathrm{T}^{+}$and $\mathrm{T}^{+}$subsets. The functional specificity of these subsets is now known to be complex and heterogeneous, with cytotoxic cells present in both subsets and the $\mathrm{T}^{+}$subset containing both suppressor inducer and immunoglobulin-production helper functions (8).

If the $\mathrm{T}^{+}{ }^{+} \mathrm{T}^{+}$cells we identified are mature and multifunctional, this implies more in vivo tissue diversity in the $T$ cell repertoire than previously suspected from numerous studies of peripheral blood. Alternatively, these cells may be comparable

Table III. Single- and Double-Labeling of Activation Antigens on Lung Lymphocytes*

\begin{tabular}{|c|c|c|c|c|c|c|c|c|c|c|c|c|}
\hline \multirow{2}{*}{$\begin{array}{l}\text { Sub- } \\
\text { ject }\end{array}$} & \multicolumn{12}{|c|}{ Percentage positive single- or double-labeled cells } \\
\hline & Tac & Tac T3 & Tac T4 & Tac T8 & DR & DR T3 & DR T4 & DR T8 & L5.1 & L5.1 T3 & L5.1 T4 & L5.1 T8 \\
\hline 1 & 4 & 4 & 4 & 1 & 25 & 16 & 15 & 9 & 25 & 11 & 10 & 9 \\
\hline 2 & 6 & 3 & 2 & 1 & 25 & 10 & 12 & 4 & 24 & 19 & 19 & 8 \\
\hline 3 & 68 & 60 & 63 & 30 & 45 & 39 & 37 & 17 & 31 & 29 & 24 & 12 \\
\hline 4 & 5 & 3 & 4 & 2 & 12 & 4 & 9 & 3 & 7 & 5 & 4 & 3 \\
\hline 5 & 50 & 41 & 28 & 37 & 43 & 31 & 26 & 24 & 42 & 32 & 22 & 32 \\
\hline 6 & 17 & 5 & 14 & 8 & 20 & 7 & 12 & 4 & 35 & 7 & 16 & 14 \\
\hline 7 & 3 & 3 & 3 & 2 & 10 & 5 & 7 & 3 & 2 & 2 & 2 & 2 \\
\hline 8 & 2 & 2 & 2 & 2 & 27 & 14 & 17 & 11 & 3 & 1 & 3 & 3 \\
\hline 9 & 3 & 3 & 0 & 2 & 17 & 12 & ND & 8 & 5 & 4 & 2 & 6 \\
\hline 10 & 6 & 6 & 6 & 6 & 10 & 4 & 5 & 6 & 14 & 12 & 13 & 10 \\
\hline
\end{tabular}

* See Table II legend for explanation of data. 
Table IV. Coincidence of Activation Antigens on Lung Lymphocytes

\begin{tabular}{ccl}
\hline & \multicolumn{2}{c}{ Percent-positive double-labeled cells } \\
\cline { 2 - 3 } Subject & Tac DR & L5.1 DR \\
\hline 4 & 3 & ND* $^{*}$ \\
5 & 15 & ND \\
6 & 2 & 3 \\
7 & 2 & ND \\
9 & ND & 5 \\
10 & 4 & ND
\end{tabular}

* Not determined.

to immature thymocytes, but undergoing differentiation in the lung. In any case, the coexpression of T4 and T8 antigens on some lung lymphocytes likely renders previous $T$ cell helper/ suppressor subset imbalance explanations of pulmonary disease pathophysiology overly simplistic.

Activation antigens delineate the state of activation rather than functional subdivision of mature $T$ cells, and are expressed on $\mathrm{T}$ cells either following in vitro activation or in vivo during the course of diseases associated with $T$ cell activation (31). Dual labeling of activation antigens and $T$-specific antigens on BAL cells allowed the identification of activated $T$ cells in unseparated lymphocyte populations even using MAbs antiTac, anti-DR, and L5.1, which detect antigens not restricted to $\mathrm{T}$ cells $(19-22,32)$. Peripheral blood $\mathrm{T}^{+}$cells contained

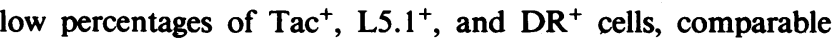
with values found by others (33). Expression of activation antigens by lung lymphocytes was highly variable, but the sum of $\mathrm{T}^{+}$and $\mathrm{T}^{+}$cells expressing the Tac or L5.1 antigen always exceeded the number of $\mathrm{T}^{+}$cells expressing the antigen. Thus, some of the $\mathrm{Tac}^{+}$cells, for example, might express both $\mathrm{T} 4$ and $\mathrm{T} 8$, or the $\mathrm{Tac}^{+}$cell membrane might be modulated during activation, such that the T3 marker is no longer expressed.

IL-2 production from BAL mononuclear cells of some sarcoid patients has previously been demonstrated (34). We have shown that lungs of normal subjects contain cells that express both IL-2 receptors and T4 or T8 antigens. IL-2 receptors may be expressed at low levels in normal lungs; alternatively, since IL-2 has perhaps a thousandfold higher

Table V. Two-Color Analysis of Cell Cycle and Surface Markers of Lung Lymphocytes*

\begin{tabular}{|c|c|c|c|c|c|c|}
\hline \multirow[b]{2}{*}{$\begin{array}{l}\text { Sub- } \\
\text { ject }\end{array}$} & \multicolumn{2}{|c|}{$\begin{array}{l}\text { Percent-positive cells } \\
\text { in stage }\end{array}$} & \multicolumn{4}{|c|}{ Percent-positive for surface marker in stage } \\
\hline & $\left(G_{0} / G_{1}\right)$ & $\left(\mathrm{S} / \mathrm{G}_{2} / \mathrm{M}\right)$ & $\begin{array}{l}\text { Tac } \\
\left(G_{0} / G_{1}\right)\end{array}$ & $\begin{array}{l}\text { Tac } \\
\left(\mathrm{S} / \mathrm{G}_{2} / \mathrm{M}\right)\end{array}$ & $\begin{array}{l}\text { DR } \\
\left(G_{0} / G_{1}\right)\end{array}$ & $\begin{array}{l}\text { DR } \\
\left(\mathrm{S} / \mathrm{G}_{2} / \mathrm{M}\right)\end{array}$ \\
\hline 6 & 92 & 0 & NDt & ND & ND & $\mathrm{ND}$ \\
\hline 7 & 88 & 2 & 3 & 2 & 6 & 2 \\
\hline 8 & 75 & 5 & ND & ND & 21 & 5 \\
\hline 9 & 88 & 1 & 0 & 0 & 18 & 1 \\
\hline
\end{tabular}

* Only samples with $>80 \%$ of lymphocytes (DNA stained) are included.

$¥$ Not determined. affinity for its receptor than does anti-Tac (24), it is possible that low anti-Tac binding in the lung reflects prior in vivo saturation of IL-2 receptor sites with IL 2.

Dual labeling was required to discriminate $\mathrm{DR}^{+} \mathrm{T}$ cells from B cells with DR antigen; the data show that DR antigens occurred on both $\mathrm{T}^{+}$and $\mathrm{T}^{+}$cells, and could be present even when Tac and L5.1 expression was low. Several reports suggest functional importance of $\mathrm{T}^{+} \mathrm{DR}^{+}$and $\mathrm{T} 8^{+} \mathrm{DR}^{+}$lymphocytes $(33,35,36)$.

L5.1 binds to the transferrin receptor, a surface molecule expressed on cells of many established cell lines but only on freshly obtained cells that are actively dividing $(22,28,29)$. On $T$ cells, transient expression of the transferrin receptor appears to require prior IL-2 receptor expression and IL-2 binding (37). In our study, ${\mathrm{L} 5.1^{+}}^{\mathrm{T}} 3^{+}$cells never exceeded $5 \%$ of total peripheral blood lymphocytes (mean $2 \%$ ), whereas the proportion of ${\mathrm{L} 5.1^{+}}^{+}$lung lymphocytes was variable never exceeding $32 \%$ of total lymphocytes of a single $T$ lineage marker. Total binding of L5.1 exceeded the sum of $\mathrm{T}^{+}, \mathrm{T}^{+}$, and $\mathrm{T}^{+}$cells in some cases, suggesting binding of the antibody to some lung lymphocytes without these $\mathrm{T}$ lineage markers.

Two-color studies of activation antigen expression as a function of cell cycle revealed nearly all lymphocytes to be in $G_{0} / G_{1}$ in these normal subjects, and in one subject, Tac was expressed both in $G_{0} / G_{1}$ and in dividing cells, as previously shown (38). However, in contrast to that report, indicating $\mathrm{DR}$ only as a "late" antigen on in vitro proliferating $\mathrm{T}$ cells, we detected $D R$ antigen on $G_{0} / G_{1}$ as well as proliferating cells in subjects 7,8 , and 9 . Although some of the $\left(G_{0} / G_{1}\right) D R^{+}$ cells may have been $\mathrm{B}$ lymphocytes, the high numbers of $\mathrm{DR}^{+}$ cells of $T$ lineage (Table III) suggest the in vivo existence of $\mathrm{DR}^{+} \mathrm{T}$ cells in $\mathrm{G}_{0} / \mathrm{G}_{1}$. These and all cell cycle data relying on fluorescent assessment of DNA content should be interpreted with caution, since assigning cell cycle stage by these techniques can vary by as much as $10-40 \%$ (39).

The pathophysiology and extent of $T$ lymphocyte participation in human immunologic lung diseases remain to be clarified. Our study can serve to provide base-line data for the unexpected range of expression of surface markers of lung $T$ cell differentiation and activation in controls. The data also show a preponderance of small lymphocytes in $G_{0} / G_{1}$ with "proliferation" antigens (Tac, L5.1) and DR antigen on $\mathrm{T}^{+}$ and $\mathrm{T}^{+}$cells, in addition to demonstrating the presence of $\mathrm{T}^{+}{ }^{+} \mathrm{T}^{+}$and $\mathrm{T}^{-}$cells. Their presence in normal controls is presumably physiologic, in response to inhaled and circulating antigens, and is an aid in determining the cellular repertoire available to the in vivo immune response.

\section{Acknowledgments}

We thank James E. Wilson for advice and support, Julie A. Titus and Lewis Lanier for fluorophore conjugation protocols, T. Juhani Linna, Peter C. Nowell, and Richard J. Robb for many helpful discussions, Marina Hoffman for editing, and Elaine Burton for typing the manuscript.

Dr. Davidson was supported by institutional training grant HL07000 from the National Institutes of Health.

\section{References}

1. Daniele, R. P., J. A. Elias, P. E. Epstein, and M. D. Rossman. 1985. Bronchoalveolar lavage: role in the pathogenesis, diagnosis, and management of interstitial lung disease. Ann. Intern. Med. 102:93108. 
2. Crystal, R. G., W. C. Roberts, G. W. Hunninghake, J. E. Gadek, J. D. Fulmer, and B. R. Line. 1981. Pulmonary sarcoidosis: a disease characterized and perpetuated by activated lung T lymphocytes. Ann. Intern. Med. 94:73-94.

3. Hunninghake, G. W., and R. G. Crystal. 1981. Pulmonary sarcoidosis: a disorder mediated by excess helper T-lymphocyte activity at sites of disease activity. N. Engl. J. Med. 305:429-434.

4. Ginns, L. C., P. D. Goldenheim, R. L. Burton, R. B. Colvin L. G. Miller, G. Goldstein, C. Hurwitz, and H. Kazemi. 1982. Tlymphocyte subsets in peripheral blood and lung lavage in idiopathic pulmonary fibrosis and sarcoidosis: analysis by monoclonal antibodies and flow cytometry. Clin. Immunol. Immunopath. 25:11-20.

5. Leatherman, A. W., A. F. Michael, B. S. Schwartz, and J. R. Hoidal. 1984. Lung T cells in hypersensitivity pneumonitis. Ann. Intern. Med. 100:390-392.

6. Keller, R. H., S. Swartz, D. P. Schlueter, S. Bar-Sela, and J. N. Fink. 1984. Immunoregulation in hypersensitivity pneumonitis: phenotypic and functional studies of bronchoalveolar lymphocytes. Am. Rev. Respir. Dis. 130:766-771.

7. Reinherz, E. L., and S. F. Schlossman. 1980. Regulation of the immune response: inducer and suppressor lymphocyte subsets in human beings. N. Engl. J. Med. 303:370-373.

8. Romain, P. L., and S. F. Schlossman. 1984. Human T lymphocyte subsets: functional heterogeneity and surface recognition structures. J. Clin. Invest. 74:1559-1565.

9. Perussia, B., S. Starr, S. Abraham, V. Fanning, and G. Trinchieri. 1983. Human natural killer cells analyzed by B73.1, a monoclonal antibody blocking $\mathrm{Fc}$ receptor functions. I. Characterization of the lymphocyte subset reactive with B73.1. J. Immunol. 130:2133-2138.

10. Mosciki, R. A., E. P. Amento, S. M. Krane, J. T. Kurnick, and R. B. Colvin. 1983. Modulation of surface antigens of a human monocyte cell line during incubation with $\mathrm{T}$ lymphocyte-conditioned medium: detection of $\mathrm{T} 4$ antigen and its presence on normal blood monocytes. J. Immunol. 131:743-748.

11. Davidson, B. L., M. D. Rossman, W. Greene, G. Koretsky, P. C. Nowell, and R. P. Daniele. 1983. Activated lung lymphocytes in normal subjects and in sarcoidosis: identification of Ia and Tac antigens on lung T cells. Am. Rev. Respir. Dis. 127(Suppl.):62. (Abstr.)

12. Nagai, S., H. Tamura, and T. Izumi. 1984. Activated T cells in BALF in sarcoidosis: comparison of $\mathrm{E} 37^{\circ} \mathrm{C}$ cells, Tac + cells, and Ia + cells. Int. Conf. Bronchoalveolar Lavage. 1:82. (Abstr.)

13. Pacheco, Y., G. Cordier, M. Perrin-Fayolle, and J. P. Revillard. 1982. Flow cytometry analysis of $\mathrm{T}$ lymphocytes in sarcoidosis. $\mathrm{Am}$ J. Med. 73:82-88.

14. Reynolds, H. Y., and H. H. Newball. 1974. Analysis of proteins and respiratory cells obtained from human lungs by bronchial lavage. J. Lab. Clin. Med. 84:559-573.

15. Saltini, C., A. J. Hance, V. J. Ferrans, F. Basset, P. B. Bitterman, and R. G. Crystal. 1984. Accurate quantification of cells recovered by bronchoalveolar lavage. Am. Rev. Respir. Dis. 130:650658.

16. Kaplan, J., D. Molan, and A. Reed. 1982. Altered lymphocyte markers and blastogenic responses associated with 24 hour delay in processing of blood samples. J. Immunol. Methods. 50:187-191.

17. Dzik, W. H., and L. Neckers. 1983. Lymphocyte subpopulations altered during blood storage. N. Engl. J. Med. 309:435-436.

18. Kung, P. C., G. Goldstein, E. L. Reinherz, and S. F. Schlossman. 1979. Monoclonal antibodies defining distinctive human T-cell surface antigens. Science (Wash. DC). 206:347-349.

19. Lampson, L. A., and R. Levy. 1980. Two populations of Ialike molecules on a human B cell line. J. Immunol. 125:293-299.

20. Engleman, E. G., R. Warnke, R. I. Fox, and R. Levy. 1981. Studies of a human $\mathrm{T}$ lymphocyte antigen recognized by a monoclonal antibody. Proc. Natl. Acad. Sci. USA. 78:1791-1795.

21. Mitchell, K. F., F. E. Ward, and H. Koprowski. 1983. DR antigens on melanoma cells: analysis with monoclonal antibodies. Hum. Immunol. 4:15-26.
22. Lebman, D., M. Trucco, L. Bottero, B. Lange, S. Pessano, and G. Rovera. 1982. A monoclonal antibody that detects expression of transferrin receptor in human erythroid precursor cells. Blood. 59:671678.

23. Uchiyama, T., T. S. Broder, and T. A. Waldmann. 1981. A monoclonal antibody (anti-Tac) reactive with activated and functionally mature human T cells. I. Production of anti-Tac monoclonal antibody and distribution of Tac (+) cells. J. Immunol. 126:1393-1397.

24. Depper, J. M., W. J. Leonard, R. J. Robb, T. A. Waldmann, and W. C. Greene. 1983. Blockade of the interleukin-2 receptor by anti-Tac antibody: inhibition of human lymphocyte activation. J. Immunol. 131:690-696.

25. Jurdic, P., C. Moscovici, S. Pessano, L. Bottero, and G. Rovera. 1982. A monoclonal antibody with specificity for leukemic cells transformed by defective avian leukemia viruses. J. Cell Physiol. 2(Suppl.):85-95.

26. Titus, J. A., R. Haughland, S. O. Sharrow, and D. M. Segal. 1982. Texas red, a hydrophilic red-emitting fluorophore for use with fluorescein in dual parameter flow microfluorometric and fluorescence microscopic studies. J. Immunol. Methods. 50:193-204.

27. Crissman, H. A., and J. A. Steinkamp. 1982. Rapid one-step staining procedures for analysis of cellular DNA and protein by single and dual laser flow cytometry. Cytometry. 3:84-89.

28. Judd, W., C. A. Poodry, and J. L. Strominger. 1980. Novel surface-antigen expressed on dividing cells but absent from nondividing cells. J. Exp. Med. 152:1430-1435.

29. Trowbridge, I. S., and M. B. Omary. 1981. Human cell surface glycoprotein related to cell proliferation is the receptor for transferrin. Proc. Natl. Acad. Sci. USA. 78:3039-3043.

30. Reinherz, E. L., S. Meuer, K. A. Fitzgerald, R. E. Hussey, H. Levine, and S. F. Schlossman. 1982. Antigen recognition by human $T$ lymphocytes is linked to surface expression of the T3 molecular complex. Cell. 30:735-743.

31. Mittler, R. S., P. E. Rao, M. A. Talle, R. Look, and G. Goldstein. 1983. Cell membrane perturbation of resting $T$ cells and thymocytes causes display of activation antigens. J. Exp. Med. 158: 99-111.

32. Korsmeyer, S. J., W. C. Greene, J. Cossman, S.-M. Hsu, J. P. Jensen, L. M. Neckers, S. L. Marshall, A. Bakhshi, J. M. Depper, W. J. Leonard, E. S. Jaffe, and T. A. Waldmann. 1983. Rearrangement and expression of immunoglobulin genes and expression of Tac antigen in hairy cell leukemia. Proc. Natl. Acad. Sci. USA. 80:4522-4526.

33. Zoumbos, N. C., P. Gascon, J. Y. Djeu, S. R. Trost, and N. S. Young. 1985. Circulating activated suppressor $T$ lymphocytes in aplastic anemia. N. Engl. J. Med. 312:257-265.

34. Pinkston, P., P. B. Bitterman, and R. G. Crystal. 1983. Spontaneous release of interleukin- 2 by lung $\mathrm{T}$ lymphocytes in active pulmonary sarcoidosis. N. Engl. J. Med. 308:793-800.

35. Reinherz, E. L., C. Morimoto, A. C. Penta, and S. F. Schlossman. 1981. Subpopulations of the $\mathrm{T}^{+}{ }^{+}$inducer $\mathrm{T}$ cell subset in man: evidence for an amplifier population preferentially expressing la upon activation. J. Immunol. 126:67-170.

36. Yachie, A., T. Miyawaki, T. Yokoi, T. Nagaoki, and N. Taniguchi. 1982. Ia-positive cells generated by PWM-stimulation within $\mathrm{OKT}^{+}$subset interact with $\mathrm{OKT} 8^{+}$cells for inducing active suppression of B cell differentiation in vitro. J. Immunol. 129:103-106.

37. Neckers, L. M., and J. Cossman. 1983. Transferrin receptor induction in mitogen-stimulated human $\mathrm{T}$ lymphocytes is required for DNA synthesis and cell division and is regulated by interleukin-2. Proc. Natl. Acad. Sci. USA. 80:3494-3498.

38. Cotner, T., J. M. Williams, L. Christenson, H. M. Shapiro, T. B. Strom, and J. Strominger. 1983. Simultaneous flow cytometric analysis of human $\mathrm{T}$ cell activation antigen expression and DNA content. J. Exp. Med. 157:461-472.

39. Dean, P. N., J. W. Gray, and F. A. Dolbeare. 1982. Analysis and interpretation of DNA distributions measured by flow cytometry. Cytometry. 3:188-195. 